\title{
DARIUSZ ADRIANOWSKI*
}

\section{SILNA MARKA A BUDOWANIE WARTOŚCI PRZEDSIĘBIORSTWA}

\section{Wstęp}

Współczesne przedsiębiorstwa za główny cel stawiają sobie budowanie wartości dla akcjonariuszy. Nieustannie zmieniające się warunki funkcjonowania firm powodują, że poszukują one coraz to nowszych źródeł swojej wartości, aby zyskać przewagę nad konkurencją. W owych poszukiwaniach coraz większą rolę odgrywają pozabilansowe aktywa niematerialne, takie jak marka, wizerunek, czy też kultura organizacyjna. Wydaje się, że największe znaczenie spośród nich odgrywa marka. To właśnie ona może być sposobem na odróżnienie organizacji i jej produktów od konkurencji, prowadząc tym samym do zbudowania przewagi konkurencyjnej oraz zwiększenia wartości firmy. Artykuł jest próbą odpowiedzi na pytanie jakie korzyści wynikają z faktu, że przedsiębiorstwo posiada silną markę.

\section{Definicje marki}

We współczesnych realiach gospodarczych aktywa niematerialne posiadają niekiedy większe znaczenie niż majątek trwały. Wartości niematerialne i prawne przyjmują różną formę, ale w większości przypadków to marka i jej kapitał odgrywają najważniejszą rolę.

Marka jest popularnym pojęciem i pełni ważną rolę w naukach o zarządzaniu. Traktowana jest jako podstawowe narzędzie marketingu. Przytoczenie definicji marki, która posiada uniwersalną akceptację, jest jednak trudne. Za markę można uznać nazwę, symbol, znak graficzny, kolor, kompozycję przestrzenną, melodię lub połączenie wcześniejszych elementów, tworzące wizerunek produktu, odróżniający się od konkurencji ${ }^{1}$. W praktyce marka rozumiana jest jako „coś więcej”, co zbudowało świadomość, reputację i ma

\footnotetext{
* Doktorant, Katedra Marketingu, Wydział Zarządzania, Uniwersytet Łódzki.

1 J. Altkorn, T. Kramer, Leksykon marketingu, Polskie Wydawnictwo Ekonomiczne, Warszawa 1998, s. 140-141.
} 
znaczenie na rynku ${ }^{2}$. Środowisko związane z marketingiem definiuje markę jako zespół cech, które zdaniem uczestników rynku wyrażają sobą firmy, produkty, usługi, a nawet osoby, kraje i organizacje ${ }^{3}$. Marka może być rozumiana na cztery różne sposoby: jako produkt, organizacja, osoba lub symbol.

Według J. Kalla marka to kombinacja złożona $\mathrm{z}$ produktu fizycznego, nazwy marki, opakowania, reklamy oraz takich działań, jak dystrybucja i cena. Zastosowanie marketingu mix powoduje, że marka zyskuje dodatkowe wartości o charakterze emocjonalnym, które wyróżniają ją na tle pozostałych ${ }^{4}$. Powyższą definicję można uznać za ogólną, ale pokazującą wiele elementów, które należy traktować jako składniki marki, dzięki czemu jest też definicją uniwersalną. Podkreśla jednocześnie możliwość osiągnięcia pozycji lidera rynkowego, co w świetle tematu pracy jest szczególnie istotne.

Opracowanie kombinacji, która odróżnia jedno zestawienie powyższych elementów od drugiego, dostarcza nabywcom ponadprzeciętnych korzyści zarówno funkcjonalnych, jak i symbolicznych, dzięki czemu formuje się lojalna grupa konsumentów i umacnia się pozycja rynkowa przedsiębiorstwa.

Markę można również scharakteryzować jako zespół funkcjonalnych, ekonomicznych i psychologicznych, korzyści, jakie stają się udziałem użytkownika produktu, $\mathrm{z}$ konkretną nazwą i konkretnym symbolem ${ }^{5}$. Marka to składnik produktu, dzięki któremu nabiera on indywidualnego charakteru, bez względu na podobne cechy z innymi produktami tej samej kategorii. Marka to nośnik informacji o produkcie, które konsument bierze pod uwagę przy zakupie. Jest to pojęcie wielowymiarowe, w skład, którego wchodzą niewidoczne procesy tworzące jej wartość dodaną i budujące przewagę konkurencyjną .

Marka określana bywa również jako znak handlowy, brand, znak towarowy. $\mathrm{Na}$ podstawie ustawy Prawo własności

${ }^{2}$ K. Keller., Strategiczne zarządzanie marka, Wolters Kluwer, Warszawa 2011, s. 20.

${ }^{3}$ http://biznes.net/blogposts/view/162, dostęp na 12.05.2012.

${ }^{4}$ A. Banaszak., Postrzeganie marki, [w:] Paluchowski W. J., Bartkowiak G. (red.), Psychologia a promocja: zachowania konsumentów, Wydawnictwo Rys Studia, Poznań 2004, s. 45-81.

5 G. Urbanek, Na początku był znak, [w:] Marki Polskie - dodatek do Rzeczpospolitej, 30.06.2004.

${ }^{6}$ L. De Chernatony, Marka. Wizja i tworzenie marki, GWP, Gdańsk 2003. 
przemysłowej ${ }^{7}$, marka to szczególna nazwa, znak, symbol, wzór lub ich kombinacja, nadawana przez sprzedawcę lub grupę sprzedawców, mająca na celu identyfikację wyrobu lub usługi oraz ich wyróżnienie na tle ofert konkurentów ${ }^{8}$. Z kolei znakiem towarowym ustawodawca określa każde oznaczenie prezentowane w sposób graficzny lub takie, które da się w sposób graficzny przedstawić, zastrzegając, iż powinno ono odróżniać towar jednego przedsiębiorstwa od tego samego rodzaju towarów innego podmiotu.

Dla wielu przedsiębiorstw marka jest jednym z najważniejszych zasobów firmy, będącym zestawem poszczególnych cech produktu, które mają wpływ na decyzje zakupowe nabywców i dzięki którym nazwa produktu będzie przez nich kojarzona. Dobra marka powinna odwzorowywać produkt i być łatwo zapamiętywana ${ }^{9}$. Marka realizuje wiele funkcji wobec nabywców. Są one spełniane tym lepiej, im wyższy jest poziom jej znajomości i akceptacji oraz lojalność w stosunku do niej.

Zgodnie z powyższymi definicjami marka powinna odróżniać dany produkt od jego rynkowych odpowiedników i dostarczać niezbędnych informacji do podjęcia ostatecznej decyzji zakupowej. Dlatego marka pełni kilka ważnych funkcji ${ }^{10}$ :

- identyfikacyjną - wskazuje na źródło pochodzenia produktu,

- ochronną - chroni przed kopiowaniem,

- gwaranta powtarzalności - marka zobowiązuje się do identycznych rezultatów stosowania, bez względu na miejsce i czas zakupu produktu,

- gwaranta jakości - niezmienna jakość, będąca wartością dla klienta,

- uproszczenia procesu decyzyjnego - pozwala zebrać i uporządkować informacje o ofercie firmy i konkurentów,

- transformacyjną - świadomość marki zwiększa i transformuje przeżycia związane z konsumpcją,

\footnotetext{
${ }^{7}$ Ustawa z dnia 30 czerwca 2000 roku Prawo własności przemysłowej, tj. Dz. U. z 2003 r., Nr 119, poz. 1117 z póź. zm.

${ }^{8}$ Dz.U. z 2001r., nr 49, poz. 508; Dz.U. z 2002r., nr 74, poz. 676; Dz.U. nr 108, poz 945; Dz.U. nr 113, poz.983; Dz.U, nr 153, poz. 1271; tekst jednolity - Dz.U. z 2003r., nr 119, poz. 1117 oraz Dz.U. z 2004r., nr 33, poz. 286; za „Biznes Trendy”, INFOR, Warszawa, maj 2006, s. 35.

${ }^{9}$ I. Rutkowski, Strategie produktu. Koncepcje i metody zarządzania oferta produktowa, PWE, Warszawa 2011.

${ }^{10}$ J. Kall, B. Sojkin, J. Szymczak, M. Urbanik, Zarządzanie produktem, PWE, Warszawa 2003, s. 56.
} 
- $\quad$ symboliczną - marka pozwala na podkreślenie swojej odrębności grupom $\mathrm{z}$ niej korzystającym $\mathrm{i}$ jest narzędziem komunikacji niewerbalnej,

- wyróżniająca - polega na wykreowaniu unikalnego wizerunku marki, który zapewni jej dużą rozpoznawalność,

- strategiczną - wszystkie działania związane z budowaniem marki stanowią istotę marketingu przedsiębiorstwa.

\section{Znaczenie marki w budowaniu wartości przedsiębiorstwa}

Współczesną gospodarkę cechuje wzrost znaczenia pozabilansowych zasobów niematerialnych $\mathrm{w}$ tworzeniu wartości przedsiębiorstwa. Dlatego w ostatnich latach kwestię marki i jej znaczenia dla organizacji badało i analizowało wielu przedstawicieli środowiska akademickiego, jak i biznesowego. Dla przedsiębiorców, menedżerów i inwestorów jest ona jednym $\mathrm{z}$ najcenniejszych aktywów firmy. Mimo jej niematerialnego charakteru i problemów z oszacowaniem wartości, stała się najważniejszym aktywem przedsiębiorstw, będącym źródłem wartości firmy i jej rynkowego sukcesu ${ }^{11}$.

Marka, sprzyjająca wzrostowi wielkości sprzedaży produktu, zyskuje na znaczeniu jako ważny zasób przedsiębiorstwa. Marka oraz inne aktywa niematerialne coraz częściej uznawane są za źródło wartości przedsiębiorstwa oraz brane są pod uwagę przy ich wycenie. Jej wycena może być pomocna, gdy marka zostaje sprzedawana lub istnieje potrzeba określenia konieczności inwestowania w kolejne kampanie wizerunkowe ${ }^{12}$.

Marki tworzą wartość zarówno dla udziałowców, jak i dla konsumentów. Budowanie wartości dla konsumentów przejawia się w niwelowaniu ryzyka zakupu produktów i uproszczenia procesu ich wyboru. Z kolei wartość dla udziałowców tworzona jest przez zwiększenie wartości przepływów gotówkowych, przyśpieszenie ich realizacji oraz zmniejszenie kosztów kapitałowych ${ }^{13}$.

Silna marka ma generować zyski. Inwestowanie w nią ma sens, jeżeli wpływa to na zwiększenie zysków przedsiębiorstwa.

11 A. Herman, A. Szablewski, Zarządzanie wartościa firmy, Poltext, Warszawa 1999, s. 291-292.

12 L. Grabowski, I. Rutkowski, W. Wrzosek, Marketing, PWE, Warszawa 2001, s. 339.

13 P. Doyle, Marketing wartości, Wydawnictwo Felberg SJA, Warszawa 2003, s. 297. 
Zarządzanie wartością marki polega na wykorzystaniu szans rynkowych i zwiększaniu zdolności marki do generowania przepływów pieniężnych ${ }^{14}$. Zarządzanie wartością marki oparte jest o odpowiednią informację, dotyczącą wyników firmy w ujęciu zorientowanym na przyszłość ${ }^{15}$.

\section{Sila marki}

Marka organizacji jest ważną wartością opiniotwórczą oraz obietnicą dodatkowych, unikalnych korzyści dla klienta, których nie mogą zaoferować inne firmy. Silna marka reprezentuje dokładnie to czego oczekują klienci, co z kolei umożliwia przedsiębiorstwu rozwój nowych produktów. Silne marki doskonale zarządzają relacjami z klientem, dzięki budowaniu emocjonalnych więzi, wykraczających poza funkcje kupowanego przez nich produktu lub usługi ${ }^{16}$.

Siła marki określa pozycję rynkową przedsiębiorstwa oraz sposób jej postrzegania przez klientów. Określa się ją poprzez porównanie pozycji danej marki z pozycją marek konkurencyjnych. Zestawienia dokonuje się, biorąc pod uwagę: pozycję rynkową, zachowania klientów wobec marki, postrzeganie marki, rodzaj rynku na którym działa marka, i inne ${ }^{17}$.

Zbudowanie silnej marki na rynku nie jest prostym zadaniem. $\mathrm{Na}$ początku należy dogłębnie zrozumieć potrzeby i oczekiwania nabywców, bo dzięki temu przedsiębiorstwo może skutecznie zarządzać jakością dostarczanych przez siebie produktów. kryteria $^{18}$ :

Ustalając siłę marki, bierze się pod uwagę następujące

- pozycja na rynku - im większa, tym bardziej stabilna i większa wartość rynkowa,

- wskaźnik świadomości istnienia marki,

- przywództwo w danej branży - określane przez konsumentów, którzy uważają markę za lidera rynkowego,

\footnotetext{
${ }^{14}$ J. Kall, R. Kłeczek, A. Sagan, Zarządzanie marka, Oficyna Ekonomiczna, Kraków 2006, s. 252.

15 A. Black, P. Wright, J. E. Bachman, $W$ poszukiwaniu wartości dla akcjonariuszy, Dom Wydawniczy ABC, Warszawa 2000, s. 273.

${ }^{16}$ P. Doyle, Marketing wartości..., op. cit. s. 260.

${ }^{17}$ I. Rutkowski, Strategia produktu..., op. cit., s. 186.

${ }^{18}$ J. Kall, B. Sojkin, J. Szymczak, M. Urbanik, Zarządzanie produktem..., op. cit., s. 62-65.
} 
- kompetencje marki - silne marki z łatwością wejdą na nowe rynki lub stworzą nowe produkty,

- elastyczność cenowa marki - jej obniżenie skutkuje mniejszym spadkiem popytu na markę,

- ponadregionalny i ponadnarodowy charakter marki,

- obecność na rynku - dłuższa obecność wskazuje na szersze grono lojalnych klientów,

- charakter rynku, na którym działa marka,

- długofalowy trend ,wartości marki”,

- działania marketingowe o odpowiedniej skali i jakości, wspierające marki,

- wrażliwość na markę - określana poprzez relatywne znaczenie marki w decyzjach klientów,

- ochrona prawna marki.

Pod pojęciem siły marki (brand power) kryje się bardzo dobry charakter osobowości marki, pozytywny i znaczący wizerunek, logiczność jej komunikacji oraz zgodność i integralność jej tożsamości ${ }^{19}$. Siłę marki można nazywać również zbiorem skojarzeń i zachowań nabywców i uczestników procesu dystrybucji, którzy decydują o utrzymaniu trwałej przewagi konkurencyjnej.

Silna marka zapewnia klientom korzyści funkcjonalne i symboliczne, dzięki czemu tworzy się lojalne grono nabywców, pozwalających firmie osiągnąć dominującą pozycję na rynku ${ }^{20}$. Elementy siły marki obrazuje rysunek 1 .

${ }^{19}$ J. Szymczak, M. Urbaniak, Marka jako element jakości postrzeganej przez nabywców instytucjonalnych, [w:] Skrzypek E. (red.), Wpływ zasobów niematerialnych na wartość firmy, tom 2, UMCS, Lublin 2003, s. 408.

${ }^{20}$ M. Kieżel, Wizerunek marki i jego znaczenie, „Marketing i rynek”, nr 6, 1999, s. 15. 


\section{Rysunek 1. Elementy sily marki}

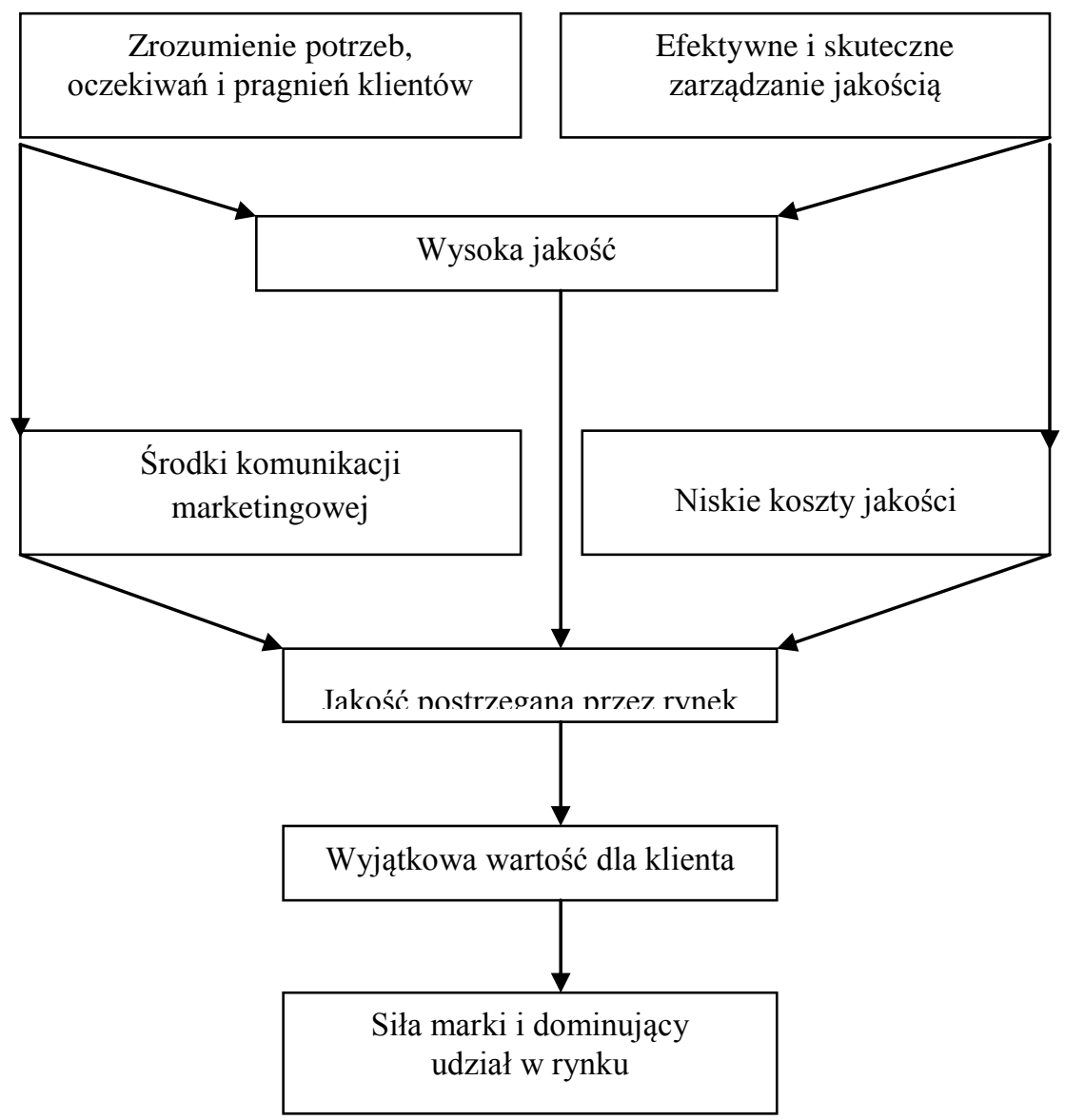

Źródło: J. Szymczak, M. Urbaniak, Marka jako element jakości postrzeganej przez nabywców instytucjonalnych, [w:] Skrzypek E. (red.), Wpływ zasobów niematerialnych na wartość firmy, tom 2, UMCS, Lublin 2003, s. 409.

Dziennik Rzeczpospolita od kilku lat prowadzi ranking najcenniejszych marek polskich, w ramach których bada również siłę marek. W rankingu, siła marki określana jest na podstawie porównania jej pozycji z markami konkurencyjnymi, do ustalenia czego służą badania rynkowe. Takie badanie zostało wykonane metodą bezpośrednich indywidualnych wywiadów na przełomie października i listopada 2011 roku na próbie losowej 1200 respondentów powyżej 15. roku życia, z miast powyżej 20 tys. mieszkańców ${ }^{21}$.

${ }^{21}$ www.ekonomia24.pl/artykul/769746.html, dostęp na 08.05.2012. 
$\mathrm{Na}$ podstawie zebranych informacji oceniano pozycję marek w czterech obszarach i przypisano im odpowiednie wagi: pozycja rynkowa marki, zachowania klientów wobec marki, postrzeganie marki oraz rodzaj rynku, na którym marka działa. Wskaźnik siły marki ma zastosowanie przy wyliczaniu wartości marek.

Tabela 1. Czynniki decydujące o sile marki

\begin{tabular}{|c|c|c|c|}
\hline $\begin{array}{c}\text { Czynnik sily } \\
\text { marki }\end{array}$ & Waga & Wskaźnik & $\begin{array}{c}\text { Wagi } \\
\text { wskaźnika }\end{array}$ \\
\hline \multirow[t]{3}{*}{ Pozycja rynkowa } & 21 & $\begin{array}{l}\text { Preferencje } \\
\text { konsumentów }\end{array}$ & $0-15$ \\
\hline & & Świadomość marki & $0-3$ \\
\hline & & Priorytet w świadomości & $0-3$ \\
\hline \multirow{2}{*}{$\begin{array}{l}\text { Relacje z } \\
\text { klientami }\end{array}$} & 24 & Lojalność klientów & $0-16$ \\
\hline & & Stopa referencji & $0-8$ \\
\hline \multirow{3}{*}{$\begin{array}{l}\text { Postrzeganie } \\
\text { marki }\end{array}$} & 45 & Prestiż & $0-20$ \\
\hline & & Postrzegana jakość & $0-20$ \\
\hline & & Postrzegana wartość & $0-5$ \\
\hline Rynek & 10 & Rodzaj rynku & $0-10$ \\
\hline Suma & 100 & Suma & $\mathbf{0}-100$ \\
\hline
\end{tabular}

Źródło: Ranking „Najsilniejsze marki 2011” Rzeczpospolita.

Zsumowanie wag przy poszczególnych markach pozwoliło na stworzenie rankingu najsilniejszych marek w 2011 roku.

Tabela 2. Ranking najsilniejszych marek 2011

\begin{tabular}{c|ccc|}
\hline Lp. & Marka & Sila marki & $\begin{array}{c}\text { Zmiana stosunku do } \\
\text { 2010r. }\end{array}$ \\
\hline 1. & Wedel & 79 & -2 \\
2. & Winiary & 78 & 0 \\
3. & Pudliszki & 76 & 1 \\
4. & Lubella & 75 & 0 \\
5. & TVN & 74 & -1 \\
6. & Sokołów & 73 & 2 \\
7. & Tymbark & 73 & 0 \\
8. & Allegro.pl & 75 & 2 \\
9. & Hortex (mrożonki) & 72 & 3 \\
10. & Apart & 72 & 1 \\
11. & Koral (lody) & 71 & 2 \\
12. & Biedronka & 71 & 2 \\
\cline { 2 - 3 }
\end{tabular}

Źródło: Ranking „Najsilniejsze marki 2011” Rzeczpospolita. 
Tabela 2. Ranking najsilniejszych marek...

\begin{tabular}{|c|c|c|c|}
\hline Lp. & Marka & Sila marki & $\begin{array}{c}\text { Zmiana stosunku } \\
\text { do 2010r. }\end{array}$ \\
\hline 13. & Żywiec Zdrój & 71 & -1 \\
\hline 14. & RMF FM & 71 & 2 \\
\hline 15. & Bakoma & 70 & 2 \\
\hline 16. & Łaciate & 70 & 4 \\
\hline 17. & Olej Kujawski & 70 & 0 \\
\hline 18. & Hortex (soki) & 70 & 0 \\
\hline 19. & Kamis & 70 & 1 \\
\hline 20. & Polsat & 69 & 2 \\
\hline 80. & Mastercook & 60 & -1 \\
\hline 81. & Lech & 60 & -2 \\
\hline 82. & Gino Rossi & 60 & -1 \\
\hline 83. & Kropla Beskidu & 60 & 3 \\
\hline 84. & Indykpol & 60 & 0 \\
\hline 85. & Fortuna & 60 & 0 \\
\hline 86. & Żołądkowa Gorzka & 60 & 3 \\
\hline 87. & Wojas & 60 & 4 \\
\hline 88. & Poczta Polska & 60 & 1 \\
\hline 89. & Gadu-gadu & 60 & - \\
\hline 90. & Diverse & 60 & 4 \\
\hline 91. & Lasocki & 60 & 1 \\
\hline 92. & Radio Eska & 60 & 2 \\
\hline 93. & Atlantic & 59 & 3 \\
\hline 94. & Cleanic & 59 & 2 \\
\hline 95. & Vistula & 59 & 5 \\
\hline 96. & Bieluch & 59 & 4 \\
\hline 97. & Cyfrowy Polsat & 59 & 2 \\
\hline 98. & Muszynianka & 59 & 2 \\
\hline 99. & Gazeta Wyborcza & 59 & 0 \\
\hline 100. & Goplana & 59 & -1 \\
\hline
\end{tabular}

Źródło: Ranking „Najsilniejsze marki 2011” Rzeczpospolita.

Po raz kolejny, miejsce lidera na liście najsilniejszych marek zajął Wedel, który najwięcej punktów uzyskał w dwóch ważnych kategoriach: prestiż i postrzegana jakość. Na uwagę zasługują marki, które zyskały największy przyrost siły. Wskaźnik siły marki o 6 punktów wzrósł dla marki Reserved (40. miejsce), Wólczanka (48. miejsce), wp.pl (51. miejsce) oraz Ziaja (72. miejsce). O 5 punktów z kolei wzrosły wskaźniki takich marek, jak Allegro.pl (8. miejsce), PZU (24. miejsce) oraz Vistula (95. miejsce). Aż trzy 
z wymienionych marek należą do branży odzieżowej, co może świadczyć o utrwalaniu ich wizerunku w polskim społeczeństwie.

W powyższym rankingu największy spadek siły marki zanotował Łosoś i Tyskie, odpowiednio o 4 i 3 punkty. Wśród stu najsilniejszych marek w 2011 roku:

- 61 odnotowało wzrost wskaźnika siły marki,

- 8 zanotowało spadek,

- 18 nie zmieniło wartości swojego wskaźnika,

- 3 marki pojawiły się pierwszy raz: Prince Polo (32. miejsce w rankingu), Grześki (37. miejsce w rankingu), Gadu-Gadu (89. miejsce w rankingu).

\section{Wpływ marki na budowanie wartości przedsiębiorstwa}

Silna i stabilna marka daje wiele korzyści dla jej klientów oraz samego przedsiębiorstwa. Przedsiębiorstwu, dobrze rozpoznawalna marka, umożliwia zwiększenie sprzedaży i wchłaniane premii cenowej $^{22}$, powoduje mniejszą zależność od wahań koniunktury, mody, czy wydarzeń rynkowych. Silna marka ułatwia skuteczną walkę $z$ konkurencją ${ }^{23}$, a także zwiększa efektywność i skuteczność kampanii marketingowych ${ }^{24}$.

Siła marki powiązana jest $\mathrm{z}$ jej znaczeniem dla organizacji, nabywców jej produktów i usług, a także dla dystrybutorów. Dzięki poczynionym krokom do stworzenia silnej marki, firma jest w stanie osiągnąc stabilną i wysoką pozycję na rynku.

Firmy konkurencyjne, chcące zbudować tak silną pozycję na rynku, mają utrudnione zadanie, ponieważ wymagałoby to znacznych nakładów czasu i pieniędzy, przy jednoczesnym wysokim ryzyku niepowodzenia, aby pokonać silnie uplasowaną konkurencję. Dlatego firmy o silnej marce są $\mathrm{w}$ stanie osiągnąć i utrzymać przewagę konkurencyjną, która pozytywnie wpływa na wartość przedsiębiorstwa.

\footnotetext{
22 M. Anklewicz, P. Kapłon P., Szansa dla firm, [w:] Marki Polskie - dodatek do Rzeczpospolitej, 30.06.2004.

${ }^{23}$ J. Wojciechowska, Marka jako zasób niematerialny firmy, [w:] Skrzypek E. (red.), Wpływ zasobów niematerialnych na wartość firmy, tom 2, UMCS, Lublin 2003, s. 423.

24 A. Baruk., Wizerunek firmy jako pracodawcy w opiniach aktualnych i potencjalnych pracowników, [w:] Skrzypek E. (red.), Wpływ zasobów niematerialnych na wartość firmy. Tom 2. UMCS, Lublin 2003, s. 353.
} 
Silna marka, oprócz atutów wizerunkowych, gwarantuje również wymierne korzyści ${ }^{25}$ :

- gwarantuje wyższą zyskowność sprzedaży,

- obniża elastyczność cenową popytu,

- pozwala łatwo wydłużyć linię produktów,

- chroni przed kampaniami promocyjnymi konkurencji,

- pozytywnie wpływa na negocjacje warunków sprzedaży z pośrednikami,

- posiada dłuższy cykl życia.

Dobra i stabilna marka uznawana jest za gwarancję jej sukcesu i wzrostu zysków w przyszłości. Marka staje się aktywem o wymiernej wartości finansowej i traktowana jest jako jedno $\mathrm{z}$ najważniejszych źródeł wartości przedsiębiorstwa. Jej szczególne znaczenie dla przedsiębiorstw uwidacznia się $\mathrm{w}$ tworzeniu i utrzymywaniu dhugotrwałej przewagi konkurencyjnej.

\section{Podsumowanie}

Silna marka pozwala odróżnić daną firmę i jej produkty od konkurencji oraz zbudować trwałą przewagę konkurencyjną i podnieść wartość firmy. Pozytywny wpływ marki na wartość przedsiębiorstwa można rozpatrywać na trzy sposoby:

- silna marka umożliwia zaakceptowanie wyższego poziomu cen przez nabywców,

- dobra marka pomaga utrwalić atrakcyjność produktów i buduje grono lojalnych nabywców,

- silna marka umożliwia oszczędności.

We współczesnej gospodarce, silna marka uważana jest za najważniejszy generator wartości przedsiębiorstwa. Wiele firm uważa ją również za najcenniejsze z aktywów.

\section{Bibliografia}

1. Ustawa $\mathrm{z}$ dnia 30 czerwca 2000 roku Prawo własności przemysłowej, tj. Dz. U. z 2003 r., Nr 119, poz. 1117 z póź. zm.

2. Altkorn J., Kramer T., Leksykon marketingu, PWE, Warszawa, 1998.

\footnotetext{
${ }^{25}$ J. Kall, B. Sojkin, J. Szymczak, M. Urbanik, Zarzadzanie produktem..., op. cit., s. $65-66$.
} 
3. Anklewicz M., Kapłon P., Szansa dla firm, [w:] Marki Polskie dodatek do Rzeczpospolitej, 2004.

4. Banaszak A., Postrzeganie marki, [w:] Paluchowski W. J., Bartkowiak G. (red.), Psychologia a promocja: zachowania konsumentów, Wydawnictwo Rys Studia, Poznań 2004.

5. Baruk A., Wizerunek firmy jako pracodawcy w opiniach aktualnych i potencjalnych pracowników, [w:] Skrzypek E. (red.), Wplyw zasobów niematerialnych na wartość firmy, tom 2, UMCS, Lublin 2003.

6. Black A., Wright P., Bachman J. E., W poszukiwaniu wartości dla akcjonariuszy, Dom Wydawniczy ABC, Warszawa 2000.

7. De Chernatony L., Marka. Wizja i tworzenie marki., GWP, Gdańsk, 2003.

8. Doyle P., Marketing wartości, Wydawnictwo Felberg SJA, Warszawa 2003.

9. Grabowski L., Rutkowski I., Wrzosek W., Marketing, PWE, Warszawa 2001.

10. Herman A., Szablewski A., Zarządzanie wartościa firmy, Poltext. Warszawa 1999.

11. Kall J., Kłeczek R., Sagan A., Zarzadzanie marka, Oficyna Ekonomiczna, Kraków 2006.

12. Kall J., Sojkin B., Szymczak J., Urbaniak M., Zarządzanie produktem, PWE, Warszawa 2003.

13. Keller K., Strategiczne zarządzanie marka, Wolters Kluwer, Warszawa 2011.

14. Kieżel M., Wizerunek marki i jego znaczenie, „Marketing i rynek”, nr 6, 1999.

15. Rutkowski I., Strategie produktu. Koncepcje i metody zarzadzania oferta produktowa, PWE, Warszawa 2011.

16. Szymczak J., Urbaniak M., Marka jako element jakości postrzeganej przez nabywców instytucjonalnych, [w:] Skrzypek E. (red.), Wpływ zasobów niematerialnych na wartość firmy, tom 2, UMCS, Lublin 2003.

17. Urbanek G., Na początku był znak, [w:] Marki Polskie - dodatek do Rzeczpospolitej, 2004.

18. Wojciechowska J, Marka jako zasób niematerialny firmy, [w:] Skrzypek E. (red.), Wpływ zasobów niematerialnych na wartość firmy, tom 2, UMCS, Lublin 2003.

\section{Strony internetowe}

1. http://biznes.net/blogposts/view/162 
2. www.ekonomia24.pl/artykul/769746.html.

\section{Streszczenie}

Artykuł podejmuje problematykę wpływu marki na budowanie wartości przedsiębiorstwa. Pierwsza jego część prezentuje różne podejścia do definicji marki oraz charakteryzuje silną markę, pokazując przy tym rosnącą rolę zasobów niematerialnych. W dalszej części analizowany jest ranking najsilniejszych polskich marek oraz zostaje podjęta próba pokazania korzystnego wpływu silnej marki na wartość całego przedsiębiorstwa.

\section{Summary}

\section{STRONG BRAND VERSUS CREATING BUSINESS VALUE}

The article takes up problems of brand's influence on creating business value. In the first part, the article presents various attitudes toward brand definition and gives characteristics of a strong brand, showing the increasing role of intangible assets. Further, the analysis of the strongest polish brands is made. In conclusion, the article presents the positive influence of a strong brand on the company value. 